\title{
Interleukins 12 and 13 levels among beta- thalassaemia major patients
}

\author{
R.A. Hashad, ${ }^{1}$ N.A. Hamed, ${ }^{2}$ M.M. El Gharabawy, ${ }^{7}$ H.A. El Metwally and M.G. Morsi ${ }^{7}$
}

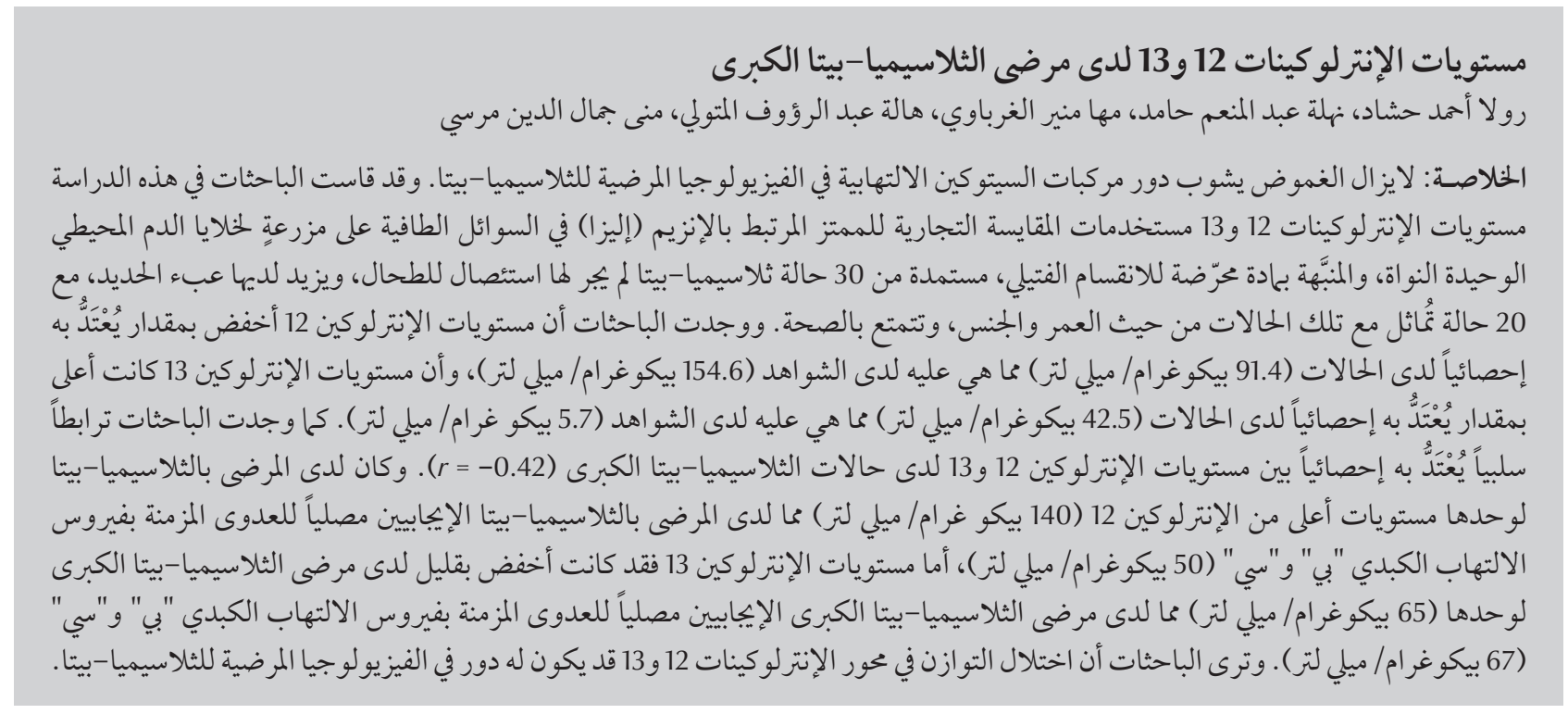

ABSTRACT The role of inflammatory cytokines in the pathophysiology of beta-thalassaemia is still unclear. In this study production levels of interleukins (IL)-12 and IL-13 were measured by commercial ELISA in culture supernatants of mitogen-stimulated peripheral blood mononuclear cells from 30 non-splenectomized betathalassaemia cases with iron overload and 20 age- and sex-matched healthy individuals. IL-12 levels were significantly lower among cases compared with controls (91.4 pg/mL versus $154.6 \mathrm{pg} / \mathrm{mL})$, while IL-13 levels were significantly higher $(42.5 \mathrm{pg} / \mathrm{mL}$ versus $5.7 \mathrm{pg} / \mathrm{mL})$. There was a significant negative correlation between IL12 and IL-13 levels among beta-thalassaemia cases $(r=-0.42)$. Patients with beta-thalassaemia alone had higher IL-12 levels than beta-thalassaemia patients who were seropositive for chronic hepatitis B or C virus infection (140 pg/mL versus $50 \mathrm{pg} / \mathrm{mL}$ ); IL-13 levels were slightly lower (65 pg/mL versus $67 \mathrm{pg} / \mathrm{mL})$. An imbalance in the IL-12/IL-13 axis may be relevant to the pathophysiology of beta-thalassaemia.

\section{Taux des interleukines 12 et 13 chez des patients atteints de bêta-thalassémie majeure}

RÉSUMÉ Le rôle des cytokines inflammatoires dans la physiopathologie de la bêta-thalassémie reste à élucider. Dans la présente étude, les taux de production des interleukines 12 et 13 (IL-12 et IL-13) ont été mesurés à l'aide de la méthode ELISA dans les surnageants de culture de cellules mononucléées de sang périphérique stimulées par des mitogènes chez 30 cas de bêta-thalassémie non splénectomisés présentant une surcharge martiale ainsi que chez 20 individus en bonne santé appariés pour l'âge et le sexe. Les taux d'IL-12 étaient nettement inférieurs chez les malades par rapport aux témoins (91,4 pg/ml contre 154,6 pg/ml), alors que les taux d'IL-13 étaient significativement plus élevés $(42,5 \mathrm{pg} / \mathrm{ml}$ contre 5,7 pg/ml). Une corrélation négative importante existait entre les taux d'IL-12 et d'IL-13 chez les patients atteints de beta-thalassémie ( $r$ $=-0,42)$. Les patients uniquement porteurs d'une bêta-thalassémie avaient des taux d'IL-12 plus élevés que les patients atteints d'une bêta-thalassémie et également chroniquement infectés par le virus de l'hépatite B ou C $(140 \mathrm{pg} / \mathrm{ml}$ contre $50 \mathrm{pg} / \mathrm{ml})$; les taux de I'IL-13 étaient légèrement inférieurs $(65 \mathrm{pg} / \mathrm{ml} \mathrm{contre}$ $67 \mathrm{pg} / \mathrm{ml}$ ). Un défaut de l'axe IL-12/IL-13 peut être révélateur de la physiopathologie de la bêta-thalassémie. 


\section{Introduction}

Thalassaemias are a worldwide problem [1]. Beta-thalassaemia is the most common type and has the highest frequency in the Mediterranean area. Heterozygotes have thalassaemia minor, a condition in which there is usually mild anaemia and little or no clinical disability. Homozygotes (thalassaemia major) are either unable to synthesize haemoglobin A or at best produce very little and, after the first 4 months of life, develop a profound hypochromic anaemia [2]. Blood transfusions may be required every 4-6 weeks [1]. However, one of the most common side-effects of blood transfusion is infection of the recipient with hepatitis $\mathrm{B}$ virus (HBV) and/or $\mathrm{C}$ virus (HCV). $\mathrm{HCV}$ is the most common transfusion-transmitted infection [2].

Several immunological defects can be found in patients with beta-thalassaemia, among which the impairment of neutrophils and macrophage phagocytic and killing functions and the production of some cytokines are the most important. The plasma levels of these cytokines may be relevant in the pathophysiology of beta-thalassaemia [3]. Interleukin (IL)-12 and IL-13 are 2 recently characterized cytokines which play an important role in the induction of T-helper cell type 1 (Th1-) and Th2like cells, respectively [4]. IL-12 has the potential for use either as a single immunotherapeutic agent, in combination with other chemotherapeutic agents, or as a vaccine adjuvant [5]. IL13 is a cytokine secreted by many cell types especially Th2 cells. It displays homology with IL-4 and shares some of its biological functions, especially with regards to changes induced on haematopoietic cells. It acts as an immunoregulatory and effector cytokine [6]. Several studies have shown that an imbalance in the IL-3/IL-7 and IL-6/IL-8 axes may contribute to the development of beta-thalassaemia major $[3,4]$. The plasma levels of IL-12 and IL-13 may also be relevant in the pathophysiology of beta-thalassaemia. To evaluate this hypothesis, IL-12 and IL-13 concentrations were investigated in beta-thalassaemia patients and controls and in relation to their HBV and HCV status.

\section{Methods}

\section{Sample}

This case-control study was done on 30 patients [ 18 males and 12 females, mean age 21.6 (SD 9.3) years] admitted to the department of haematology at Alexandria Main University hospital, Egypt, during the year 2010 with a final diagnosis of beta-thalassaemia major. The inclusion criteria were all cases who were non-splenectomized, HIV negative and having iron overload. They were diagnosed from complete blood count, haemoglobin electrophoresis and high serum ferritin, with bone marrow confirmation. Age- and sex-matched controls were 20 healthy volunteers [ 8 males and 12 females, mean age 21.3 (SD 11.9)] from among hospital staff (doctors, technicians and laboratory workers) who were HBV, $\mathrm{HCV}$ and HIV negative. Informed consent was taken from all subjects participating in the study. All those enrolled were subjected to the following: history taking, full clinical assessment, complete blood count and liver and renal function tests.

\section{Data collection}

Estimation of IL-12 and IL-13 levels was done by isolation of peripheral blood mononuclear cells (PBMCs) from heparinized venous blood by Ficoll-Hypaque density layer centrifugation (Sigma) and cultured at $2 \times 10^{5}$ cells per $500 \mu \mathrm{L}$ Rosell Park Memorial Institute (RPMI) 1640 medium supplemented with antibiotics and 5\% fetal calf serum (FCS). For stimulation, $5 \mu \mathrm{g} / \mathrm{mL}$ phytohaemagglutinin mitogen (PHA, Wellcome) was used.
Incubation of cultures was performed at $37^{\circ} \mathrm{C}$ in a humidified atmosphere of $5 \% \mathrm{CO}_{2}$. After 2 days of culture, supernates were collected from each tube and stored at $-20^{\circ} \mathrm{C}$ to be assayed using commercial ELISA kits (RayBio) were followed according to manufacturers' instructions $[7,8]$.

$\mathrm{HBsAg}$ and HCV Abs were detected by ELISA HBsAg test system 2 and HCV version 3.0 ELISA test system (Ortho-Clinical Diagnostics) [9,10].

\section{Data analysis}

SPSS, version 15.0 for Windows was used for analysis of the data. The 5\% level of significance was taken to test the significance of the results obtained; $P \leq 0.05$ was considered significant. Data were shown as mean and standard deviation (SD).

\section{Results}

Table 1 shows the IL- 12 and IL- 13 levels among both studied groups. In the control group IL-12 levels ranged from $46.2-243.9(\mathrm{pg} / \mathrm{mL})$, with a mean of 154.6 (SD 61.1) pg/mL, while patients' levels ranged from $40.4-135.4 \mathrm{pg} / \mathrm{mL}$ with a mean of $91.9(\mathrm{SD} 28.5) \mathrm{pg} /$ $\mathrm{mL}$, a highly significant difference $(P$ $<0.001)$. IL-13 levels among controls ranged from $2.7-8.5 \mathrm{pg} / \mathrm{mL}$, with a mean of 5.7 (SD 1.8) pg/mL, while patients' values ranged from 9.9-65.0 $\mathrm{pg} / \mathrm{mL}$ with a mean of 42.5 (SD 18.0) $\mathrm{pg} / \mathrm{mL}$, also a highly significant difference $(P<0.001)$.

There were 4 beta-thalassaemic patients who were seropositive for $\mathrm{HBV}$ and $\mathrm{HCV}$ infection. There was no correlation between IL-12 and IL-13 among controls, but there was a significant negative correlation between IL-12 and IL-13 levels, i.e. a decrease in IL-12 with increasing IL-13, among cases of beta-thalassaemia $(n=26)(r=-0.42$, $P=0.003$ ). Figure $1 \mathrm{a}$ and $1 \mathrm{~b}$ shows the IL-12 and IL-13 levels of controls and patients with thalassaemia major and 


\begin{tabular}{|c|c|c|c|c|c|c|}
\hline \multirow[t]{2}{*}{ Variable } & \multicolumn{2}{|c|}{$\begin{array}{l}\text { Controls } \\
(n=20)\end{array}$} & \multicolumn{2}{|c|}{$\begin{array}{c}\text { Cases } \\
(n=30)\end{array}$} & \multirow[t]{2}{*}{$t$-test } & \multirow[t]{2}{*}{$P$-value } \\
\hline & Mean (SD) & Range & Mean (SD) & Range & & \\
\hline IL-12 level (pg/mL) & $154.6(61.1)$ & $46.2-243.9$ & $91.9(28.5)$ & $40.4-135.4$ & 14.7 & $<0.001$ \\
\hline IL-13 level (pg/mL) & $5.7(1.8)$ & $2.1-8.5$ & $42.5(18.0)$ & $9.9-65.0$ & 21.5 & $<0.001$ \\
\hline
\end{tabular}

$S D=$ standard deviation.

those co-infected with $\mathrm{HBV}$ or $\mathrm{HCV}$. Patients with beta-thalassaemic alone had higher IL-12 levels [140 (SD 10.7) $\mathrm{pg} / \mathrm{mL}$ ] compared with those coinfected with chronic HBV and HCV
[50 (SD 5.5) pg/mL]. In contrast, IL13 levels were higher among chronic viral hepatitis [(67 (SD 3.6) pg/mL] cases compared with beta-thalassaemic patients $[65(5.7) \mathrm{pg} / \mathrm{mL}]$.

\section{Discussion}

Recent evidence suggests that levels of IL-8, tumour necrosis factor and a soluble receptor of IL-2 (sCD25)
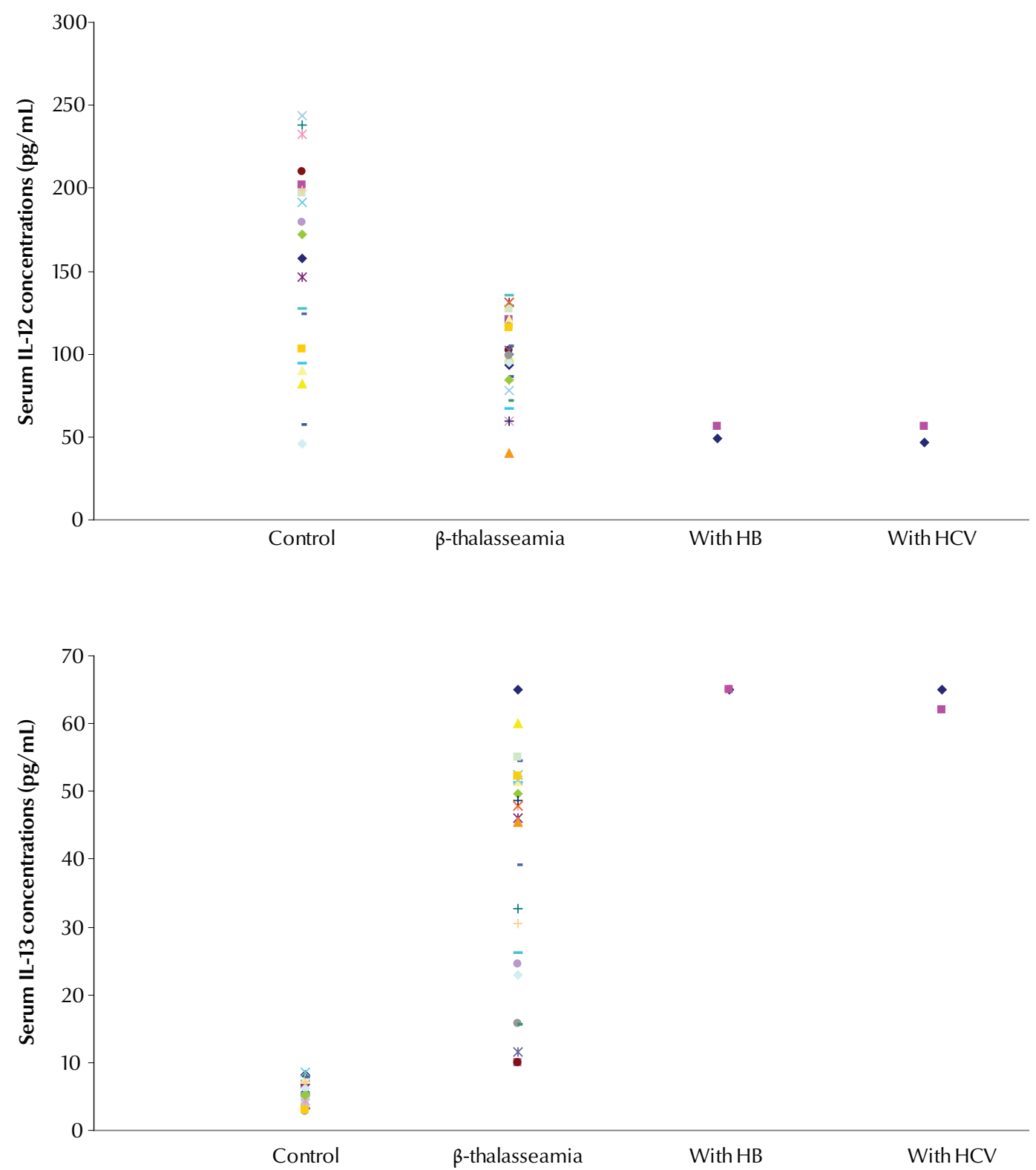

Figure 1 Comparison of interleukin (IL) levels in controls $(n=20)$, patients with beta-thalassaemia alone $(n=26)$ and patients with beta-thalassaemia plus hepatitis B virus $(\mathrm{HBV})(n=4)$ or hepatitis C virus $(\mathrm{HCV})$ infection $(n=4)$ 
and imbalances in the IL-3/IL-7 and IL-6/IL-8 axes may have biological and clinical importance in thalassaemic patients [11]. Our data demonstrates that IL-12 production was significantly suppressed in thalassaemic patients $(91.9 \mathrm{pg} / \mathrm{mL})$ compared with controls $(154.6 \mathrm{pg} / \mathrm{mL})$, indicating the involvement of this cytokine in the suppression of erythropoiesis in thalassaemic patients, similar to the involvement of IL-3 in erythropoiesis of thalassaemic patients [12] and it suggests that IL-12 is a cytokine involved in the cellular immunological alterations in beta-thalassaemia. Meanwhile patients with beta-thalassaemia were found to have significantly higher IL-13 concentrations $(42.5 \mathrm{pg} / \mathrm{mL})$ than normal controls $(5.7 \mathrm{pg} / \mathrm{mL})$. Our data suggests that there could be an intrinsic cause for the IL-13 increase in thalassaemia major. This increase downregulates macrophage activity thereby inhibiting production of proinflammatory cytokines and chemokines [13]. IL-13 needs to be studied in detail in order to learn more about the involvement of this cytokine in erythropoiesis of thalassaemic patients.
Substantial evidence suggests that an imbalance in production of these 2 critical immunoregulatory cytokines (i.e. overproduction of IL-13 and impairment of IL-12 production) may be associated with cellular immunological alterations in beta- thalassaemia. Although it is not entirely clear what tips the balance between these cytokines, the potential role of IL-12 and IL-13 and the interaction between them in thalassaemic patients require further investigation. These findings clearly agree with the results of Willskarp who suggested that an imbalance in the production of IL-12 and IL-13 occurs in the lung of atopic and asthmatic individuals [14]. In our study a significant negative correlation was found between IL-12 and IL-13 levels ( $r=$ -0.42 ). Meanwhile, there was no correlation between these 2 inflammatory cytokines in normal controls. From these observations we can conclude that an imbalance in the IL-12/IL-13 axis may be relevant in the pathophysiology of beta-thalassaemia.

Beta-thalassaemic patients had higher serum IL-12 levels (140 pg/ $\mathrm{mL}$ ) compared with those of chronic hepatitis B or C patients $(50 \mathrm{pg} / \mathrm{mL})$. On the other hand, serum IL-13 concentrations in patients with chronic viral hepatitis $(67 \mathrm{pg} / \mathrm{mL})$ were slightly higher compared with those of thalassaemia patients $(65 \mathrm{pg} / \mathrm{mL})$. These findings clearly agree with the results of Uguccioni et al. [15]. Similar values were also reported by Di Marco et al. [16]. Several other studies have investigated the role of cytokines and interleukins in the pathophysiology of beta-thalassaemia [17-22].

Our data and those from the literature strongly support the hypothesis that beta-thalassaemia major is associated with a downregulation of IL-12 and an upregulation of IL-13 which leads to an imbalance in IL-12/IL-13 axis which may be relevant in the pathophysiology of beta-thalassaemia. HBV and HCV, probably resulting from repeated blood transfusion, may aggravate the condition. These cytokines deserve more investigation on larger samples as well as in vivo trials in experimental animals, as they may be a target for immunotherapy to clear hepatitis virus infection (resulting from repeated transfusion) and raise patients' immunity.

\section{References}

1. Edwards C, Bouchier I. Davidson's principles and practice of medicine, 16th ed. Edinburgh, Churchill Livingstone 1991.

2. Shang G et al. Residual risk of transfusion-transmitted viral infections in Shenzhen, China, 2001 through 2004. Transfusion, 2007, 47:529-539.

3. Oztürk $O$ et al. Increased plasma levels of interleukin- 6 and interleukin-8 in beta-thalassaemia major. Haematologia, 2001, 31:237-244.

4. Kutukculer $\mathrm{N}$ et al. Plasma interleukin-3 (IL-3) and IL-7 concentrations in children with homozygous beta-thalassemia. Journal of Tropical Pediatrics, 1997, 43:366-367.

5. Gately MK, Mulqueen MJ. Interleukin-12: potential clinical application in the treatment and prevention of infectious diseases. Drugs, 1996, 52(Suppl. 2):18-25.

6. Wynn TA. IL-13 effector functions. Annual Review of Immunology, 2003, 21:425-456.

7. O'Neill LAJ, Bowie A eds. Interleukin protocols (methods in molecular medicine). Totawa, New Jersey, Humana Press, 2001.

8. Morsi MG, Atta HY, Rabie AK. Comparative study of different test systems for measuring cytokine production among tuberculous andhealthy persons. Egyptian Journal of Immunology, 1998, 5:153-162.
9. Valentine-Thon E et al. European proficiency testing program for molecular detection and quantitation of hepatitis B virus DNA. Journal of Clinical Microbiology, 2001, 39:4407-4412.

10. Tobler LH et al. Impact of HCV 3.0 EIA relative to HCV 2.0 EIA on blood-donor screening. Transfusion, 2003, 43:1452-1459.

11. Rund D, Rachmilewitz E. Beta-thalassemia. New England Journal of Medicine, 2005, 353:1135-1146.

12. Kutukculer $\mathbf{N}$ et al. Plasma interleukin-3 (IL-3) and IL-7 concentrations in children with homozygous beta-thalassemia. Journal of Tropical Pediatrics, 1997, 43:366-367.

13. Sakamoto O et al. Interleukin-13 selectively suppresses the growth of human macrophage progenitors at the late stage. Blood, 1995, 85:3487-3493.

14. Willskarp M. IL-12/IL-13 axis in allergic asthma. Journal of Allergy and Clinical Immunology, 2001, 107(7):9-18.

15. Uguccioni $M$ et al. Elevated interleukin-8 serum concentrations in beta-thalassemia and graft-versus-host disease. Blood, 1993, 81:2252-2256.

16. Di Marco V et al. Alpha interferon treatment of chronic hepatitis C in beta-thalassaemia. Gut, 1993, 34(2 Suppl.):S142-S143.

17. Lombardi $\mathrm{G}$ et al. Serum levels of cytokines and soluble antigens in polytransfused patients with beta-thalassemia 
major: relationship to immune status. Haematologica, 1994, 79:406-412.

18. Dore F et al. Serum interleukin-8 levels in thalassemia intermedia. Haematologica, 1995, 80:431-433.

19. Kutukculer $\mathrm{N}$ et al. Plasma interleukin-3 (IL-3) and IL-7 concentrations in children with homozygous beta-thalassemia. Journal of Tropical Pediatrics, 1997, 43:366-367.

20. Oztürk $O$ et al. Increased plasma levels of interleukin- 6 and interleukin-8 in beta-thalassaemia major. Haematologia, 2001, 31:237-244.
21. Di Marco V et al. Liver disease in chelated transfusion dependent thalassemics: the role of iron overload and chronic hepatitis C. Haematologica, 2008, 93:1243-1246.

22. Angelucci E et al. Italian Society of Hematology practice guidelines for the management of iron overload in thalassemia major and related disorders. Haematologica, 2008, 93:741-752.

\section{Community genetics services: report of a WHO consultation on community genetics in low-and middle- income countries}

The objective of the above-mentioned Consultation was to develop an evidence-based report on community genetics services to provide guidance to low- and middle-income countries (LMIC) in accordance with the 2008-2013 Action plan for the global strategy for the prevention and control of noncommunicable diseases (NCDs). The high rates of congenital disorders in LMIC may result in part from: low availability of public health measures for the care and prevention of these disorders; high frequency of haemoglobinopathies in Africa, the Middle-East and South-East Asia; high rates of consanguineous marriage in the Eastern Mediterranean and South-East Asia regions that can increase the occurrence of recessively inherited diseases; advanced maternal age at conception in many such countries which increases the risk of chromosomal trisomies; and large family size that may increase the number of affected children in families with autosomal recessive conditions. While noting that prevention programmes have been successfully implemented in some LMIC (e.g. Bahrain, Cyprus and Iran), the Group emphasized the need to upgrade community genetics services in LMIC and the need for education in genetics to be provided to all health professionals, policy-makers and the general public. This also included sensitization to ethical, legal and social issues which are of key concern in the context of congenital disorders and genetic diseases.

This document is available at: http://whqlibdoc.who.int/publications/2011/9789241501149_eng.pdf 